\title{
Are Peruvians Enticed by the "China Model"? Chinese Investment and Public Opinion in Peru
}

\author{
Kerry Ratigan ${ }^{1}$
}

Accepted: 30 January 2021 / Published online: 18 March 2021

(C) The Author(s), under exclusive licence to Springer Science+Business Media, LLC, part of Springer Nature 2021

\begin{abstract}
China's economic involvement in Latin America has increased dramatically in the twenty-first century, often due to China's demand for natural resources. Chinese President Xi Jinping and his government have actively courted Latin America to pave the way for economic interactions. Chinese leaders have been working to foster China's "soft power" abroad. Nonetheless, we know relatively little about how Latin Americans perceive China and how Latin Americans' experiences with Chinese firms over the past two decades have shaped their views. Have Chinese efforts at cultivating "soft power" worked? Or have the actions of Chinese mining firms damaged China's reputation? Using the Latin American Public Opinion Project (LAPOP) coupled with data on Chinese investments in Peru, I examine Peruvians' views of China and whether Peruvians think China should be a model for their country. I find that while Peruvians generally trust the Chinese government, only a small proportion prefers China as a model for Peru. The relationship between Chinese investment and public opinion is mixed. However, Peruvians who strongly value democracy are less likely to prefer China as a model for their country. The data also suggest that China still has an opportunity to shape public opinion in Peru, despite conflicts with Peruvian communities over mining projects.
\end{abstract}

Keywords China $\cdot$ Latin America $\cdot$ Peru $\cdot$ Public opinion $\cdot$ China model

\section{Introduction}

In his speech at the 19th Party Congress, President Xi Jinping declared: “...the path, the theory, the system, and the culture of socialism with Chinese characteristics have kept developing, blazing a new trail for other developing countries to achieve modernization. It offers a new option for other countries and nations who want to speed up their

Kerry Ratigan

kratigan@amherst.edu

1 Amherst College, Amherst, MA, USA 
development while preserving their independence; and it offers Chinese wisdom and a Chinese approach to solving the problems facing mankind" (Xi 2017). Although the Chinese Communist Party (CCP) leadership subsequently eased up on such rhetoric, China's unprecedented success with economic reforms offers an enviable track record. Scholars have rightly pointed out that there is no cohesive "China model" (Kennedy 2010), and, even if there were such a model, it would be difficult if not impossible to replicate. Yet China's increasingly global prominence begs the question: do citizens of developing countries find a "China model" attractive?

Although China has established a significant presence in Latin America, we know relatively little about how Latin Americans perceive China and how Latin Americans' experiences with Chinese firms over the past two decades have shaped their views. Have Chinese efforts at cultivating "soft power" worked? Or has Chinese firm behavior damaged China's reputation? Using the Latin American Public Opinion Project (LAPOP) coupled with data on Chinese investments in Peru, I examine Peruvians' views of China and whether Peruvians think China should be a model for their country. Peru provides an instructive case to examine the impacts of Chinese investment projects on public opinion. As in many developing countries, Chinese firms in Peru engage in large-scale extractive projects, such as mining copper and other metals. These projects can yield benefits for the host's economy, but also produce negative externalities such as environmental destruction and disruptions to local communities.

To preview the findings, the data suggest that Peruvians' overall opinion of China is positive, as trust in the Chinese government is high, particularly relative to trust in the US government, in the most recent waves of survey data. Chinese firms' behavior in extractive projects could have a slight negative effect on local communities' opinion of China, but the data show rather weak evidence to this effect. Rather, trust in the Chinese government is strongly associated with choosing China as a model for Peru. By contrast, Peruvians who prefer a democratic system are less likely to choose China as a model for their country. Overall, the data do not suggest that large numbers of Peruvians are interested in adopting China as a model for their own country.

This article proceeds as follows. First, I review discussions of authoritarian diffusion and whether China is spreading a "model." Second, I examine previous research on public opinion of China in Latin America. Third, I introduce China's role in Peru. Fourth, I present hypotheses related to the factors that may predict preference for China as a model for Peru and trust in the Chinese government. I then discuss the data, variables, and measurement. Next, I present the findings, which suggest mixed perceptions of China in Peru. I then present two illustrative case studies of how Peruvian communities have responded to Chinese mining projects and discuss these cases in the context of the statistical findings. Finally, I offer caveats and concluding thoughts on the implications of the analysis for the diffusion of a "China model."

\section{Authoritarian Diffusion and a "China Model"?}

Scholars and politicians often assume that China's growing economic influence will translate into diffusion of Chinese economic or political practices. This diffusion could occur through two processes. First, the Chinese government could intentionally wield its considerable power to coerce or encourage other countries to adjust their behavior. 
Second, other countries may be persuaded to voluntarily emulate aspects of Chinese governance. Previous research, including some of the articles in this special issue, has examined whether there is evidence that Chinese actors may be seeking to translate economic clout into political influence. As will be discussed below, scholars have found relatively few instances of Chinese coercion or persuasion thus far, although the potential exists.

Public opinion of China may affect the likelihood of authoritarian diffusion. In democratic countries, citizens' views of China may, theoretically, pressure political elites to emulate China or chart a different course. Similarly, political elites may consider public opinion when deciding whether and how to collaborate with the Chinese government. Therefore, if Chinese economic activity affects global public opinion and public opinion impacts the likelihood of "China model" diffusion, then we can learn about the prospects for diffusion by examining the impact of Chinese economic activity on public opinion.

Some scholars argue that certain types of authoritarian regimes are more likely to proliferate their ideology than others. Weyland argues that there are two distinct patterns of authoritarian diffusion: ideology-driven and interest-driven (Weyland 2017). Using this framework, Weyland argues that the Soviet Union was motivated by messianic ideology and actively worked to spread its form of government but that most current autocracies are driven by interests and less concerned with spreading an ideology (with the notable exception of Venezuela). Thus, Weyland suggests that current autocracies are not causing authoritarian diffusion. Similarly, Brownlee finds that democratic backsliding across the globe should be attributed to factors other than authoritarian promotion (Brownlee 2017). These studies provide an insightful macroanalysis on these questions, but they focus on regime change in the aggregate. I provide a different perspective by examining the possibility of subtle changes in Peruvians' public opinion toward China, which may indicate the likelihood of Peruvian emulation or collaboration with China.

As China has gained international prominence for rapid economic growth and political stability, observers wonder whether China's success will lead to diffusion of the Chinese Communist Party'spolitical practices and undermine democratic governance, particularly in developing countries. Ambrosio suggests that there are two pathways for authoritarian diffusion: a logic of appropriateness and a logic of effectiveness (Ambrosio 2010). If authoritarian regimes persist, their mere existence may normalize authoritarianism as a legitimate choice for governing institutions and facilitate the proliferation of autocracies, following the logic of appropriateness. If authoritarian regimes are highly effective at governing, other countries may seek to emulate them through authoritarian institutions, following the logic of effectiveness. Ambrosio examines whether there is evidence of diffusion of the "China model" or the "Beijing consensus" through content analysis of news media. He does not find evidence for increased positive perceptions of the "China model" or "Beijing consensus" following either logic (Ambrosio 2012). Ambrosio advances our understanding of this question, but his media study is limited as the media are likely to have a pro-democracy bias, which may not reflect the views of the country's leadership or citizenry.

China could be using its economic influence to shape the domestic politics of other countries or create an environment that is more favorable to China's continued global expansion. However, Castañeda finds that Chinese FDI and development loans in Latin 
America follow economic interests related to trade, commodity markets, and natural resources (Castañeda 2017). Although these activities may have soft power benefits for China, Castañeda finds that their primary motivation is economic, not political. Similarly, Gallagher and Irwin find that most Chinese finance in Latin America is directed toward natural resources, "do not track political alignments and are largely offered at market rates" (Gallagher and Irwin 2017). Gallagher and Irwin note that the tendency of Chinese policy banks to fund infrastructure projects enables China to project soft power while advancing economic goals. In a different vein, Su and Vargas Delgado conclude that China is not yet a hegemonic challenge to the United States in Latin America through their case study of financing of Nicaragua's interoceanic canal project ( $\mathrm{Su}$ and Vargas Delgado 2017).

Nonetheless, China's economic activities have implications for perceptions of China and general empathy toward the country. Chinese investment, finance, or aid that provides employment, revenue, or infrastructure may improve public perceptions of China. Through her probing analysis into the opaque world of Chinese development aid, Stallings argues that Chinese aid to Latin America serves political purposes in three ways: by responding to demands from the region, by using aid as an incentive for states to abandon diplomatic recognition of Taiwan, and to create goodwill for projects that entail natural resource extraction (Stallings 2017).

Chinese economic activities in Latin America can affect public perceptions, even if in unintended ways. Public perceptions may, in turn, affect the likelihood of political elites to emulate or collaborate with China. Following a "China in the World" approach, as advocated by Fravel, Manion, and Wang in the introduction of this special issue, I examine whether Chinese investment is associated with public opinion of China in Peru (Fravel et al. 2021).

\section{Public Opinion Toward China in Latin America}

Research on Latin Americans' views of China is nascent but growing. Most scholars find Latin Americans have a "mildly strong and mildly positive" (Armony and Velásquez 2016) view of China. Latin Americans generally feel that Chinese influence in the region is positive overall. But Latin Americans also correctly identify problems with Chinese businesses such as environmental degradation and labor disputes, although objectively Chinese firms may not be worse offenders in these areas than their counterparts from the United States and Europe (Guo and Myers 2017; Irwin and Gallagher 2013). Armony and Velásquez find that Latin Americans "admire Chinese material and scientific development, [but] they are less enthusiastic about Chinese cultural production and its projection in Latin America" (Armony and Velásquez 2016). Similarly, Carreras finds that Latin Americans have a generally positive view of China, but do not find Chinese culture particularly attractive and do not seek to emulate China's political or economic model (Carreras 2017). Latin Americans also raise concerns about neocolonialism, which is often articulated in racist tropes (Armony and Velásquez 2015).

Many Latin Americans may not have formed opinions about China's role in the region. Using datasets from 2005-8, 2010, and 2012 in Latin America, Aldrich and Lu find high rates of nonresponse in survey questions pertaining to China (Aldrich and Lu 
2015). Aldrich and Lu also find that Latin Americans had higher rates of nonresponse for China-related questions than respondents in surveys in East Asia and the United States. In the LAPOP data for Peru, the response rates for the question about trust in the Chinese government and trust in the US government were comparable, although the response rate for the US question was somewhat higher, particularly in the 2017 wave. These comparable response rates suggest that Peruvians have had the time and experience to formulate opinions about China, although nonresponse is still a concern in these questions, as will be discussed in the section on caveats. However, lack of familiarity with China may not be as significant an issue as it once was, especially in a country like Peru with many high-profile Chinese investment projects.

\section{Chinese Presence in Peru}

Chinese involvement in Peru and several other resource-rich Latin American countries is driven by extractive industries. Extractive industries have myriad implications for host communities; they can be a boon for the economy and local employment, but they may also destroy ecosystems, pollute the environment, or force communities to relocate. Thus, Chinese firms' efforts at resource extraction are often met with resistance from potential host communities. As these businesses have spearheaded China's increasing involvement in Latin America, it is relevant to note two differences in how Chinese firms operate as compared to foreign investors from other countries.

First, Chinese firms tend to prefer to acquire the rights to a mine or to purchase a mine, rather than purchasing the raw material on the market. This approach to resource extraction requires an intimate relationship between the Chinese mining firm - which has at least some connection to the Chinese party-state - and the host community. Because of this approach, the firm has a strong, visible presence in the community and controls possible impacts on the community, such as employment (i.e., how many local residents are employed by the project), working conditions (e.g., workplace safety, salary, benefits), and management of the environmental consequences of resource extraction. Many host countries are developing countries with weak institutions that may have difficulty ensuring that local regulations are enforced or that may have weak protections for workers or the environment, allowing greater flexibility for the investor. That said, Gallagher and Irwin found that Chinese firms' degree of compliance with local regulations is comparable to that of their counterparts from other countries, although Chinese infractions might be more widely publicized (Irwin and Gallagher 2013). Similarly, Guo and Myers find that concerns over China's "land grabs" are overblown and these types of events are very rare among agricultural investment projects in Latin America (Guo and Myers 2017).

Second, Chinese mining firms are either state-owned or have a close relationship with the Chinese party-state. This government support has important implications for firm behavior and perceptions of Chinese investment. Chinese firms are often able to work with a longer time horizon as they can rely on low-interest loans from state banks (Gonzalez-Vicente 2011). In addition, Chinese firms can more easily establish cooperative arrangements with other state-owned enterprises to build infrastructure in the host country or establish distribution networks for the Chinese market. These relationships, both in terms of financing and other support, are crucial to the firm's success when abroad. Chinese economic influence can also exert pressure on foreign governments and foreign firms to portray China in a 
favorable light or adjust policies according to China's interests, as discussed by Kastner and Pearson in this special issue (Kastner and Pearson 2021). However, this close link to the Chinese state can be a double-edged sword when it comes to gaining a foothold abroad. Due to its ties to the Chinese party-state, Chinalco's bid to increase its share in Río Tinto met with intense debate in Australia (Gonzalez-Vicente 2011) as did Huawei's proposal for telecommunications equipment in the United States, because of a perceived security risk (Wolf 2012). In both cases, the reaction of the host country might have differed if the firm were perceived as independent of its home government. Indeed, the perception of Chinese firms as potential agents of the state may have some empirical support. Kastner and Pearson in this special issue examine some of the levers that the Chinese state has available to control firms, state-owned enterprises in particular (Kastner and Pearson 2021). Thus, Chinese firms are often considered to be linked to the Chinese party-state, whether they are nominally private or not.

Peru provides a useful test case for public opinion of China in Latin America. China is currently Peru's largest trading partner. The Peruvian government considers mining to be fundamental to national development and has encouraged increased investment from China. Chinese investment in extractive industries has steadily increased and continues to do so in the country, although these projects are often environmentally destructive and contentious. The losers in these projects tend to be poor, indigenous, rural communities who suffer the environmental consequences with little economic benefit, but the Peruvian government continues to favor resource extraction.

The Peruvian government has actively sought greater investment from China. Peru was the third country in Latin America to recognize the People's Republic, as opposed to Taiwan. Peru signed a free-trade agreement with China in 2008, which facilitates investment in mining, energy, and infrastructure development, particularly as relevant for mining and fishing (EFE 2009). A Chinese delegation has also proposed significant infrastructure development in the country, such as a railroad which would link Piura in northern Peru and perhaps Brazil and other countries for mineral transport (EFE 2009). Strauss finds that Peruvian and Chinese elites mirror each other's rhetoric regarding contentious issues, emphasizing complementarity between the two economies while sidelining Peruvian workers and their complaints (Strauss 2012).

Peru has been a leader regarding transparency in mining, and, therefore, we might expect that the Peruvian state would be better equipped to regulate foreign firms than some host countries. The country joined the Extractive Industries Transparency Initiative (EITI) in 2007 and was the first country to be assessed as compliant with the EITI 4 years later (Ray et al. 2015). In 2011, Peru enacted a law of prior consultation which stipulates that indigenous communities have the right to consultation before the state implements policies that would impact them, such as natural resource extraction (Ray et al. 2015). However, the law of prior consultation is not always enforced and the Peruvian state often provides support to mining firms, such as police forces to provide security, rather than protecting the interests of local communities.

\section{Hypotheses}

If Peruvian public opinion favors China, then Peruvian political elites are more likely to consider emulating or collaborating with China. Thus, public opinion of China can 
shed light on whether Peru would be a propitious environment for diffusion of a "China model." Using the LAPOP survey data, I examine the factors associated with Peruvians choosing China as a model for development for their country and for expressing trust in the Chinese government. If the individual chooses China as a model or expresses trust in the Chinese government, I refer to that outcome as "expressing a favorable view of China" in the hypotheses and some portions of the analysis. That said, although trust in China and choosing China as a model are associated with each other, between 60 and 70 percent of respondents who said that they trusted China did not choose China as a model in the three waves of the survey that included the model country question (2012, 2014, and 2017), suggesting that respondents might have thought differently about the trust and model country questions. ${ }^{1}$ I test three categories of hypotheses: experience with China, personal ideology, and trust in China and the United States.

First, Peruvians' experiences with and knowledge of Chinese investment in Peru may shape their perceptions of China. As previously discussed, China's most intimate and visible involvement with Peruvian economy and society is through extractive industries. If Chinese mining firms are associated with unfavorable opinions of China, then these firms may be negatively impacting China's reputation. I posit that Peruvians who live in a region with Chinese investment may have experienced negative externalities from Chinese investment more directly and, therefore, may be less likely to express a favorable view of China (H1). Because the negative externalities of extractive industries affect rural areas most directly, I further posit that rural areas with Chinese investment will be less likely to express a favorable view of China in Hypothesis 1a. Similarly, as a proxy for knowledge of Chinese involvement in Peru, I hypothesize that Peruvians who follow the news more frequently are less likely to express favorable opinions of China.

Hypothesis 1. Peruvians in regions with Chinese investment are less likely to express a favorable view of China.

Hypothesis 1a. Peruvians in rural regions with Chinese investment are less likely to express a favorable view of China.

Hypothesis 2. Peruvians who follow the news more frequently are less likely to express a favorable view of China.

Second, ideological orientation may explain Peruvians' perceptions of China. Individuals who consider themselves to be "leftist" and who also perceive the CCP as leftist may feel an ideological affinity with China's ruling class. Thus, these individuals may be more likely to prefer China as a model for Peru because they perceive China as embodying their preferred ideological orientation. Thus, I propose:

Hypothesis 3. Peruvians who identify as more ideologically "leftist" are more likely to express a favorable view of China.

\footnotetext{
${ }^{1}$ Small proportions of respondents who did not trust China still chose China as a model, between 11 and 18 percent in all three waves.
} 
Democratic values may reduce the attractiveness of China as a model. Peruvians who prefer a democratic political system may not consider China to be an appropriate model or may have less trust in a non-democratic government, yielding Hypothesis 4:

Hypothesis 4. Peruvians with strong democratic values are less likely to express a favorable view of China.

Third, Peruvians may perceive China and the United States as offering two competing models of development. Armony and Velásquez find that US influence "is expected to decline in contrast with the Chinese rise" (Armony and Velásquez 2016) suggesting the possible replacement of an old hegemon by a rising one. I expect that Peruvians who perceive China as trustworthy are more likely to choose China as a model for development. If Peruvians perceive China and the United States as two distinct and competing models, I expect that Peruvians who do not trust the United States will be more likely to choose China as a model. Thus, I posit Hypotheses 5 and 6.

\section{Hypothesis 5. Peruvians who trust the Chinese government are more likely to prefer China as a model for development.}

Hypothesis 6. Peruvians who trust the US government are less likely to express a favorable view of China.

Support for H5 and H6 suggests that Peruvians may perceive the United States and China as distinct, competing models.

\section{Data and Measurement}

I used survey data from the four most recent waves of LAPOP $(2012,2014,2017,2019)$ and data on Chinese investment from the China Global Investment Tracker. Summary statistics are in the Appendix. I have two dependent variables: choosing China as a model for Peru and trust in the Chinese government. The "model for Peru" question was asked in three waves of the survey $(2017,2014$, and 2012) and phrased as follows: "In your opinion, which of the following countries should be a model for our country's future development?' Respondents could choose: China, Japan, India, the United States, Singapore, Russia, South Korea, Brazil, Venezuela, or Mexico. Some respondents said none or that Peru should follow its own model, but enumerators were instructed not to articulate this option. I coded this variable as 1 if the respondent chose China and 0 if the respondent chose another country, none, or that Peru should follow its own model.

In all four recent waves of LAPOP, enumerators asked about trust in the Chinese government. The question was: "In your opinion, is the government of China very trustworthy, somewhat trustworthy, not very trustworthy, not at all trustworthy, or no opinion?" When trust in the Chinese government is a dependent variable, I coded it as 1 if the respondent chose "very" or "somewhat trustworthy" and 0 for "not very trustworthy" or "not at all trustworthy."

I examine three categories of independent variables: experience and knowledge of China, personal ideology, and trust in China and the United States. 
I measure experience with China through the presence of local Chinese investment. "Chinese investment" captures whether the region (departamento) ${ }^{2}$ where the respondent was interviewed hosts a Chinese investment project, where 1 denotes Chinese investment and 0 denotes no investment. The investment data were compiled from the China Global Investment Tracker (CGIT) published by the American Enterprise Institute and the Heritage Foundation. One limitation of the CGIT is that the database only includes investments valued at US\$ 100 million or more. I expect that the omission of small investment projects will have little impact on this analysis as large investment projects are more likely to affect individuals' lives and shape public opinion. The CGIT does not provide information on the Peruvian region where the investment is located. However, because these projects are large, their location was straightforward to identify through the firm's website or by searching media coverage of the investment project. All projects included were extractive projects except for one that was classified as "utilities" in the dataset. I only included projects that had begun at least 2 years prior to the data in question to allow for the effects of investment to be felt by the local community. For example, a project that began in 2012 was not included in the analysis of the 2012 wave of the LAPOP survey but was included in analyses of subsequent waves of the survey. LAPOP also records whether the respondent lives in a rural or urban area. I coded "rural" as 1 and urban as 0 . I include an interaction term in the models to capture rural residents who have Chinese investment in their region ("Chinese investment $\times$ rural").

I measure knowledge of China through the frequency of the respondent's news media consumption. Frequency of following the news is captured through the question: "How frequently do you follow the news, on television, the radio, newspapers, or the Internet?" Respondents could choose daily, several times per week, several times per month, several times per year, or never. I coded daily or several times per week as 1 and other answers as 0 . It is worth noting that over 89 percent of respondents chose daily or several times per week in all four waves of the survey.

I capture personal ideology through three measures: left-right ideology, support for democracy, and pride in the Peruvian political system. "Ideology (rightist)" is a measure of self-described political ideology on a scale of 1 to 10 , where 10 represents the most rightist and 1 represents the most leftist. "Democracy is the best form of government" is measured by responses to the following question: "Do you agree or disagree with the following statement: 'Democracy may have its problems, but it is better than any other form of government." Reponses could range from 1 for strongly disagree to 7 for strongly agree. "Proud of Peruvian political system" is measured by the question: "To what degree do you feel proud to live under Peru's political system?" Reponses could range from 1 for "not at all" (nada) to 7 for "a lot/very" (mucho).

Trust in the Chinese and American governments is measured through two questions in which enumerators asked: "I'd like to ask you about how much you trust the governments of some countries. For each country, please tell me, in your opinion, is it very trustworthy, somewhat trustworthy, not very trustworthy, or not at all

\footnotetext{
${ }^{2}$ Peruvian departamentos are the highest administrative division in the country below the national level. There are 24 departamentos: Amazonas, Ancash, Apurímac, Arequipa, Ayacucho, Cajamarca, Callao, Cusco, Huancavelica, Huánuco, Ica, Junín, La Libertad, Lambayque, Lima, Loreto, Madre de Dios, Moquegua, Pasco, Piura, Puno, San Martín, Tacna, Tumbes, and Ucayali.
} 
trustworthy." Enumerators then listed the governments of China and the United States. When using trust as the dependent variable, I coded responses as 1 for "very trustworthy" or "somewhat trustworthy" and 0 for "not very trustworthy" or "not at all trustworthy." When using trust as an independent variable, I coded the question as follows: 4, "very trustworthy"; 3, "somewhat trustworthy"; 2, "not very trustworthy"; and 1, "not at all trustworthy."

I also included several control variables in the model. Following the convention, "Woman" takes a value of 1 if the enumerator deemed that the respondent appeared to be a woman and 0 otherwise. "Age" is calculated based on the respondent's self-reported year of birth. "Education" is measured based on the number of years of school completed by the respondent. "Income" is measured by the question: "In which of the following ranges do you find your monthly family income, including remittances and income from all the working adults and children?" Enumerators then offered 16 categories, adjusted appropriately depending on the year in which the survey was conducted.

I included regional fixed effects in all models to control for unobserved regional variation. As I used Peruvian regions (departamentos) to create the Chinese investment variable, I used a geographic variable from LAPOP for regional fixed effects. LAPOP designates seven geographic regions at a higher level than departamentos in PeruCosta Norte, Costa Sur, Lima Metropolitana, Selva, Sierra Centro, Sierra Norte, and Sierra Sur - which I used for regional fixed effects.

LAPOP's survey weights were used in computing the models.

\section{Findings}

First, if China offers an appealing model for Peruvians, I expect to see high levels of trust in the Chinese government and high proportions of Peruvians choosing China as a model for Peru. The descriptive statistics present a mixed picture on these questions. Trust in the Chinese government is indeed high and surpasses trust in the US government in 2017 and 2019 (Fig. 1). Figure 1 shows high and stable trust in the Chinese government, while trust in the US government drops dramatically in 2017. I would speculate that the drop in trust in the United States is due to President Trump's election and recent US policy toward the region, but this issue is beyond the scope of this study. ${ }^{3}$

\footnotetext{
${ }^{3}$ Research on how the Trump administration may have impacted global public opinion of the United States has mixed findings. The Pew Research Center has found that global public opinion of the United States has nearly universally declined since 2016. In Pew's 2018 Global Attitudes Survey of 25 countries (excluding Peru), the researchers found that 70 percent of respondents had no confidence in President Trump and that opinions of the United States were low and had declined since the Obama presidency (Bialik 2020; Wike et al. 2018). However, the Pew data also show that many countries (at least half of those surveyed) continued to have a favorable view of the United States in 2018 (Bialik 2020). In the 2020 wave of the same Pew survey, a majority of respondents in most of the countries surveyed expressed a favorable view of the United States, although views of President Trump were very negative (Wike et al. 2020). Agadjanian and Horiuchi find that, although many people object to President Trump, their opinion of the United States is shaped by US policy, rather than dislike for the current president, suggesting that opinions of the United States may be more resistant to an unpopular president than expected (Agadjanian and Horiuchi 2020). The LAPOP data from Peru are not sufficiently nuanced to capture whether Peruvians' levels of trust in the US government should be attributed to President Trump, recent US policy, or some other factor. Nonetheless, I expect that US leadership and recent policy are likely to play a role in Peruvians' overall trust in the United States.
} 
Slightly higher proportions of Peruvians chose China as a model in 2017 as compared to the previous two waves, while the same proportion for the US dropped slightly, but not as dramatically as trust in the US government. Slightly more than 25 percent of Peruvians chose China as model in 2017, making China the most popular choice for that year (Japan was second with slightly less than 25 percent and the United States third with 22 percent). ${ }^{4}$ Thus, these data suggest a stable and favorable impression of China, but do not point to a strong or dramatically increasing interest in adopting China's system as a model for Peru. Peruvians seem to still be divided between their interest in the US, Japanese, and Chinese systems, although trust in the US government was waning in the most recent wave of LAPOP. The steady, but low, support for China as a model suggests that there is little evidence for diffusion of a "China model" in Peru for the near term. Despite China's notable policy successes, Peruvians are not yet enticed by the prospect of emulating China.

Next, I conducted logistic regressions of choosing China for a model for Peru's development and trust in the Chinese government. The statistical results are mixed. Tables 1 and 2 show the results. First, I discuss the analysis of choosing China as a model for Peru's development. The experience with and knowledge of China variables are mixed, but somewhat favorable for China. The coefficient for Chinese investment is negative in the 2017 and 2014 waves of the survey, but not statistically significant. However, in pareddown models (e.g., omitting both trust variables), the coefficient for Chinese investment was negative and statistically significant at the $p<0.05$ level for the 2017 data, although other results were consistent. Thus, although the evidence is not strong, the data suggest the potential for direct experience with Chinese extractive projects to dampen enthusiasm for China. Thus, Chinese firms may be undermining China's reputation abroad in some instances, but public opinion may also be shaped by factors other than firm behavior.

On the other hand, respondents in rural areas were more likely to choose China as a model in some cases. Rural respondents without Chinese investment nearby were more likely to choose China as a model in 2014. In all three waves, rural respondents with Chinese investment nearby were more likely to choose China as a model for development, but this coefficient was not statistically significant in 2014. Furthermore, Peruvians who follow the news more frequently were more likely to choose China as a model, and this coefficient was statistically significant in the 2017 data, but not in the 2014 or 2012 data. These findings contradict my expectations and suggest that Peruvians may, under some circumstances, be more likely to choose China as a model if they have greater experience or knowledge of China. Despite conflicts with Chinese firms, rural communities may consider China's economic successes to be an enticing path to follow.

The three measures of ideology also suggest mixed results regarding the relationship between ideology and support for China as a model for Peru. First, the coefficient for being ideologically rightist is negative, suggesting that left-leaning Peruvians may be more likely to choose China as a model, but these coefficients are not statistically significant in any of the three waves. ${ }^{5}$ Thus, the data may not support Hypothesis 3 regarding ideology, but the models do not directly contradict this hypothesis either.

\footnotetext{
${ }^{4}$ In 2014, the United States was the most popular choice (29\%), with Japan second (28\%) and China third (19\%). In 2012, Japan was the most popular choice (29\%), with the United States second (24\%) and China third $(20 \%)$.

${ }^{5}$ Like the investment variable, this coefficient is statistically significant in the 2017 data in a pared-down model.
} 


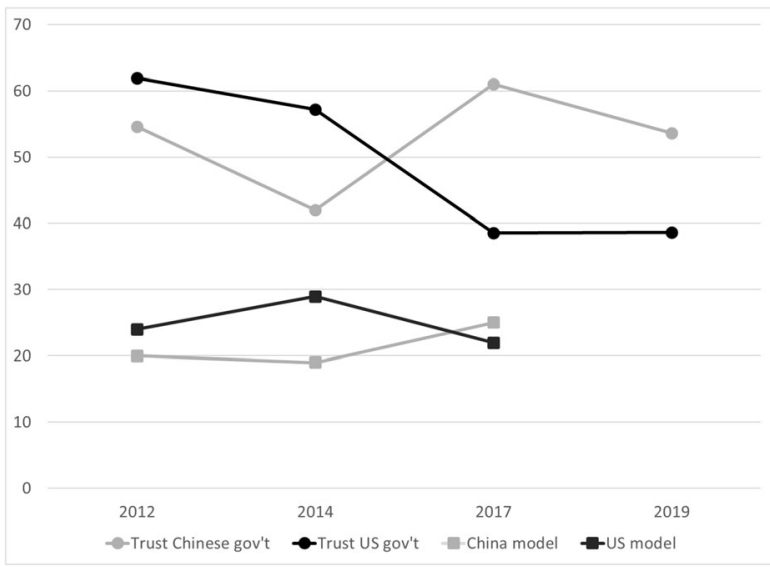

Fig. 1 Percent of respondents choosing China or the United States as a model for Peru and percent expressing trust in the Chinese and US governments. Source: The AmericasBarometer by the Latin American Public Opinion Project (LAPOP), www.LapopSurveys.org

Second, there is evidence to suggest that Peruvians who believe that democracy is the best form of government are less likely to choose China as a model for Peru. The coefficient for this variable is negative in the 2017 and 2012 waves of the data and statistically significant at the $p<0.05$ level in the 2017 wave. Thus, the data support Hypothesis 4 regarding preference for democracy. This finding suggests that entrenched democratic values may reduce the likelihood of authoritarian diffusion.

Third, Peruvians who are proud of the Peruvian political system are surprisingly more likely to choose China as a model for their country in the 2017 wave. However, the coefficient for this variable is negative and not statistically significant for 2014 and 2012. Therefore, the data offer mixed results regarding the relationship between preference for the Peruvian system and choosing China as a model (Hypothesis 5).

The most powerful and consistent predictors of the likelihood of choosing China as a model are trust in the Chinese government and trust in the US government. First, as expected, the models provide strong support for Hypothesis 6: trust in the Chinese government is strongly associated with choosing China as a model, and the relevant coefficient is statistically significant at the $p<0.01$ level in all three waves. By contrast, trust in the US government is negatively associated with choosing China as model for Peru in all three waves and statistically significant in 2017 and 2012. These two results taken together suggest that Peruvians may perceive China and the United States as distinct and possibly competing models.

The coefficients for the control variables are not statistically significant, apart from the coefficient for income in the 2017 wave. Wealthier Peruvians are less likely to choose China as a model. One can imagine at least three explanations for this association. First, wealthier Peruvians are benefitting from the current political and economic system and may not see a need for change. Second, wealthier Peruvians may be more politically conservative and not feel an ideological affinity with China's communist ruling party. Third, wealthier Peruvians may be concerned with environmental degradation and may prefer a development model that promotes conservation. Further research could examine this association. 
Table 1 Logistic Model of Choosing China as a Model For Peru's Future Development

\begin{tabular}{|c|c|c|c|}
\hline China as a model for Peru & 2017 & 2014 & 2012 \\
\hline Chinese investment & $\begin{array}{l}-0.411 \\
(0.212)\end{array}$ & $\begin{array}{c}-0.167 \\
(0.311)\end{array}$ & $\begin{array}{l}0.298 \\
(0.408)\end{array}$ \\
\hline Rural (no Chinese investment) & $\begin{array}{l}-0.210 \\
(0.205)\end{array}$ & $\begin{array}{l}0.756^{*} \\
(0.403)\end{array}$ & $\begin{array}{l}0.051 \\
(0.504)\end{array}$ \\
\hline Chinese investment $\times$ Rural & $\begin{array}{l}0.429 * \\
(0.253)\end{array}$ & $\begin{array}{l}0.325 \\
(0.505)\end{array}$ & $\begin{array}{l}0.941 * \\
(0.560)\end{array}$ \\
\hline Follows the news & $\begin{array}{l}0.753 * * \\
(0.328)\end{array}$ & $\begin{array}{l}0.100 \\
(0.516)\end{array}$ & $\begin{array}{l}0.604 \\
(0.613)\end{array}$ \\
\hline Ideology (rightist) & $\begin{array}{l}-0.042 \\
(0.029)\end{array}$ & $\begin{array}{l}-0.024 \\
(0.051)\end{array}$ & $\begin{array}{c}-0.033 \\
(0.078)\end{array}$ \\
\hline Democracy is best form of gov't & $\begin{array}{l}-0.106^{* *} \\
(0.047)\end{array}$ & $\begin{array}{l}0.008 \\
(0.071)\end{array}$ & $\begin{array}{c}-0.042 \\
(0.091)\end{array}$ \\
\hline Proud of Peruvian political system & $\begin{array}{l}0.097 * * \\
(0.044)\end{array}$ & $\begin{array}{l}-0.027 \\
(0.070)\end{array}$ & $\begin{array}{l}-0.039 \\
(0.091)\end{array}$ \\
\hline Trust Chinese gov't & $\begin{array}{l}0.922 * * * \\
(0.094)\end{array}$ & $\begin{array}{l}0.866^{* * * *} \\
(0.151)\end{array}$ & $\begin{array}{l}1.189 \text { *** } \\
(0.198)\end{array}$ \\
\hline Trust US gov’t & $\begin{array}{l}-0.392 * * * \\
(0.083)\end{array}$ & $\begin{array}{l}-0.151 \\
(0.146)\end{array}$ & $\begin{array}{l}-0.378 * * \\
(0.156)\end{array}$ \\
\hline Sex & $\begin{array}{l}-0.050 \\
(0.146)\end{array}$ & $\begin{array}{l}0.117 \\
(0.217)\end{array}$ & $\begin{array}{l}0.369 \\
(0.269)\end{array}$ \\
\hline Age & $\begin{array}{l}0.002 \\
(0.005)\end{array}$ & $\begin{array}{c}-0.003 \\
(0.007)\end{array}$ & $\begin{array}{l}0.002 \\
(0.009)\end{array}$ \\
\hline Education & $\begin{array}{l}-0.002 \\
(0.022)\end{array}$ & $\begin{array}{l}-0.000 \\
(0.034)\end{array}$ & $\begin{array}{c}-0.012 \\
(0.040)\end{array}$ \\
\hline Income & $\begin{array}{l}-0.036^{* * *} \\
(0.017)\end{array}$ & $\begin{array}{c}-0.018 \\
(0.030)\end{array}$ & $\begin{array}{l}0.005 \\
(0.043)\end{array}$ \\
\hline Regional fixed effects & Yes & Yes & Yes \\
\hline Observations & 1158 & 672 & 392 \\
\hline
\end{tabular}

Source: The AmericasBarometer by the Latin American Public Opinion Project (LAPOP), www. LapopSurveys.org; China Global Investment Tracker (The American Enterprise Institute and Heritage Foundation)

Significance codes: $* p<0.10 * *, p<0.05 * * *, p<0.01$

Next, I conducted logistic regressions with trust in the Chinese government as the dependent variable and the same independent variables as the previous models (omitting trust in the Chinese government as an independent variable.) Table 2 reports these results.

The findings from these models are sometimes inconclusive and perplexing but do provide another perspective on the question of Peruvians' views of China. The Chinese investment variable is positively associated with trust in China in all four waves, but the coefficient is not statistically significant. However, rural residents with Chinese 
Table 2 Logistic Model of Trust in Chinese Government

\begin{tabular}{|c|c|c|c|c|}
\hline $\begin{array}{l}\text { Dependent variable: } \\
\text { Trust Chinese gov't=1 }\end{array}$ & 2019 & 2017 & 2014 & 2012 \\
\hline Chinese investment & $\begin{array}{l}0.415 \\
(0.389)\end{array}$ & $\begin{array}{l}0.051 \\
(0.203)\end{array}$ & $\begin{array}{l}0.122 \\
(0.248)\end{array}$ & $\begin{array}{l}0.173 \\
(0.322)\end{array}$ \\
\hline Rural (no Chinese investment) & $\begin{array}{l}-0.270 \\
(0.851)\end{array}$ & $\begin{array}{l}-0.029 \\
(0.194)\end{array}$ & $\begin{array}{l}0.160 \\
(0.332)\end{array}$ & $\begin{array}{l}0.758^{*} \\
(0.406)\end{array}$ \\
\hline Chinese investment $\times$ Rural & $\begin{array}{l}-1.435^{* * *} \\
(0.641)\end{array}$ & $\begin{array}{l}0.087 \\
(0.241)\end{array}$ & $\begin{array}{l}0.283 \\
(0.402)\end{array}$ & $\begin{array}{l}0.721 \\
(0.523)\end{array}$ \\
\hline Follows the news & $\begin{array}{l}-0.331 \\
(0.602)\end{array}$ & $\begin{array}{l}0.279 \\
(0.257)\end{array}$ & $\begin{array}{l}0.606 \\
(0.421)\end{array}$ & $\begin{array}{l}0.357 \\
(0.429)\end{array}$ \\
\hline Ideology (rightist) & $\begin{array}{l}-0.137 * * \\
(0.068)\end{array}$ & $\begin{array}{l}-0.008 \\
(0.027)\end{array}$ & $\begin{array}{l}-0.061 \\
(0.040)\end{array}$ & $\begin{array}{l}-0.029 \\
(0.060)\end{array}$ \\
\hline Democracy is best form of gov't & $\begin{array}{l}0.054 \\
(0.101)\end{array}$ & $\begin{array}{l}0.040 \\
(0.044)\end{array}$ & $\begin{array}{l}-0.034 \\
(0.056)\end{array}$ & $\begin{array}{l}-0.008 \\
(0.076)\end{array}$ \\
\hline Proud of Peruvian political system & $\begin{array}{l}-0.088 \\
(0.096)\end{array}$ & $\begin{array}{l}0.012 \\
(0.041)\end{array}$ & $\begin{array}{l}-0.021 \\
(0.054)\end{array}$ & $\begin{array}{l}0.016 \\
(0.076)\end{array}$ \\
\hline Trust US gov't & $\begin{array}{l}0.729 * * * \\
(0.167)\end{array}$ & $\begin{array}{l}0.585 * * * \\
(0.077)\end{array}$ & $\begin{array}{l}0.769 * * * \\
(0.113)\end{array}$ & $\begin{array}{l}0.576^{* * * *} \\
(0.132)\end{array}$ \\
\hline Sex & $\begin{array}{l}-0.096 \\
(0.303)\end{array}$ & $\begin{array}{l}-0.190 \\
(0.137)\end{array}$ & $\begin{array}{l}-0.092 \\
(0.169)\end{array}$ & $\begin{array}{l}-0.203 \\
(0.219)\end{array}$ \\
\hline Age & $\begin{array}{l}-0.034 * * * \\
(0.010)\end{array}$ & $\begin{array}{l}-0.005 \\
(0.005)\end{array}$ & $\begin{array}{l}-0.010 * \\
(0.006)\end{array}$ & $\begin{array}{l}-0.007 \\
(0.007)\end{array}$ \\
\hline Education & $\begin{array}{l}0.120^{* * *} \\
(0.056)\end{array}$ & $\begin{array}{l}0.106 * * * \\
(0.020)\end{array}$ & $\begin{array}{l}0.042 \\
(0.027)\end{array}$ & $\begin{array}{l}0.069 * * \\
(0.034)\end{array}$ \\
\hline Income & $\begin{array}{c}-0.023 \\
(0.036)\end{array}$ & $\begin{array}{l}0.043 * * * \\
(0.015)\end{array}$ & $\begin{array}{l}0.039 \\
(0.024)\end{array}$ & $\begin{array}{l}0.061 * \\
(0.036)\end{array}$ \\
\hline Regional fixed effects & Yes & Yes & Yes & Yes \\
\hline Observations & 265 & 1178 & 717 & 441 \\
\hline
\end{tabular}

Source: The AmericasBarometer by the Latin American Public Opinion Project (LAPOP), www. LapopSurveys.org; China Global Investment Tracker (The American Enterprise Institute and Heritage Foundation)

Significance codes: $* p<0.10, * * p<0.05, * * * p<0.01$

investment in their region were less likely to trust China in 2019, with the coefficient statistically significant at the $p<0.05$ level. The coefficient for following the news is positive in three waves and negative in one wave, but not statistically significant. Overall, I interpret these mixed findings to suggest that Peruvian public opinion of China is likely to be quite malleable and Chinese actors still have an opportunity to shape Peruvian public opinion through their interactions with the local community. Thus, Chinese firm behavior has not condemned China to unfavorable public opinion, although it may have a dampening effect under some circumstances.

Right-leaning respondents were less likely to trust the Chinese government in all four waves, although the coefficient for this variable is only statistically significant in 2019. The possibility of an ideological affinity between leftist Peruvians and the 
Chinese Communist Party, which appears in both sets of models, could provide an opportunity for China to bolster its support in Peru and elsewhere in Latin America.

Older respondents were less likely to trust the Chinese government, and this coefficient was statistically significant in 2019 and 2014. More educated respondents were more likely to trust the Chinese government, and this coefficient was statistically significant in 2019, 2017, and 2012. Wealthier respondents were more likely to trust the Chinese government in three waves, but this coefficient was only statistically significant in 2017.

One puzzling result of the trust models is that trust in the US government is positively associated with trust in the Chinese government, with statistically significant coefficients in all four waves. A possible explanation is that some individuals are more likely to trust foreign governments in general, regardless of the country in question.

The significance of preference for democracy suggests that the attractiveness of the "China model" has inherent limitations in countries where the population has come to expect and value some degree of democratic governance. Other research has found that Latin Americans may hold in high esteem some Chinese achievements in science and technology, but are much more skeptical about following China's political model (Armony and Velásquez 2016; Carreras 2017). My findings bolster this interpretation in the Peruvian context. Furthermore, the importance of democratic values in this analysis suggests that scholars examining authoritarian diffusion ought to consider local conditions more carefully, in addition to the actions of the authoritarian regime. Whether a country emulates a foreign model is likely to be affected by both domestic factors and the appeal of the foreign model.

Taken together, the models in Table 1 and Table 2 suggest that Peruvians may think about the trust question and the model country question differently. One may, for example, consider Chinese actors to be effective engines of economic growth and, therefore, find the Chinese model appealing, but still not consider the Chinese government to be trustworthy. On the other hand, one may consider the Chinese government to be trustworthy overall, but not find China as an attractive model for Peru due to its lack of democratic institutions. In a similar vein, Xiaojun Li in this special issue finds that Canadians have consistently preferred to expand economic ties with China and continue engagement with China to resolve global challenges, despite sometimes expressing highly unfavorable attitudes toward China (Li 2021).

But is China as a model likely to gain appeal in Peru? Based on the previous analysis, let us assume that Peruvians who value democracy are less likely to choose China as a model for their country. The LAPOP data suggest that significant proportions of Peruvians value democracy and, therefore, would be less likely to support China as a model. Figure 2 shows the distribution of responses to the question regarding democracy being the best form of government.

For all four waves, more respondents agree that democracy is preferable than disagree. A clear majority of respondents chose 5 or higher on a scale of 1-7, where 1 is strongly disagree and 7 is strongly agree. Small proportions of respondents disagreed strongly that democracy is preferable. That said, a slight shift toward the center of the distribution is noticeable from 2012 to 2019. By 2019, fewer respondents strongly agreed with the statement, and more respondents chose 4 or 5 out of the 7 point scale. Certainly, preference for democracy persists in Peru, although enthusiasm for democracy might have slightly dampened in recent years. If this trend continues and 


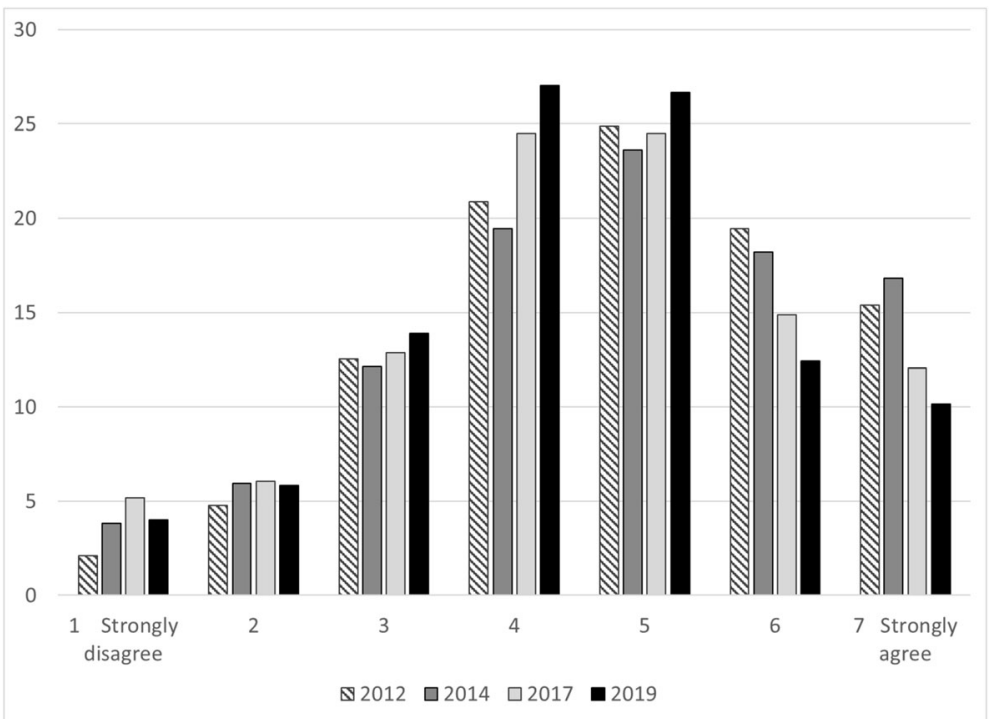

Fig. 2 Distribution of responses to the question: "Do you agree or disagree with the following statement? 'Democracy may have its problems, but it is better than any other form of government." Source: The AmericasBarometer by the Latin American Public Opinion Project (LAPOP), www.LapopSurveys.org

more Peruvians become lukewarm about democracy, there might be the possibility of greater appeal of a "China model." If US prestige continues to decline in Latin America, China may have an opportunity to fill the void through strategic corporate social responsibility, development aid, humanitarian assistance, and technical exchanges, particularly in the context of the COVID-19 pandemic.

\section{Divergent Impacts of Chinese Mining in Peru}

Case studies of Chinese mining projects and the subsequent reactions of the host community can shed light on the mixed findings of the statistical analysis. While some Chinese firms have faced constant opposition from the local community, others have managed to garner enough support to achieve the firm's aims. Zijin's Río Blanco project and Chinalco's Toromocho project illustrate both the contentious dynamics that arise and how Chinese firms have learned to ameliorate conflict in some cases.

Although Peru represents a favorable context for Chinese firms to acquire mining rights, these initiatives often encounter resistance from host communities. Despite national support for these types of projects, Zijin Consortium's attempt at developing the Río Blanco copper project, in northern Peru, was stalled for 7 years and canceled in 2015. The nature of the project, pre-existing local resistance with significant organizational capacity, and the inability of the firm to placate the local community all contributed to the ultimate failure of Zijin's venture.

The Zijin Consortium consists of Zijin (the largest gold producer in China), Tongling (copper producer), and Xiamen CyD (an investment conglomerate). In 2007, the Consortium managed to purchase a majority share (79.9 percent) of the British company Monterrico Metals, which controlled the Río Blanco copper project 
through Majaz Metals, Monterrico's subsidiary (El Comercio 2007c; El Comercio 2007b; El Comercio 2007a). However, Zijin inherited a complex conflict with the local community that its British counterparts had failed to resolve.

The Río Blanco project had been plagued by controversy prior to Zijin's involvement. Majaz Metals had ongoing conflicts with local residents because of the environmental impact of open-cast copper mining in the area. Since 2004, when Majaz began exploration in Río Blanco, the activist Gregorio Santos Guerrero initiated a campaign against mining in the region with a broad-based coalition consisting of the teachers' union (Sindicato Unitario de Trabajadores de la Educación del Perú, Sutep), left-wing members of the Church, the Peruvian Communist Party, and community members (El Comercio 2012a). Some critics of Santos speculate that Monterrico Metals was sold to Zijin because of this pressure from activists (Comercio 2012a). ${ }^{6}$ The protests led to calls from the community for a referendum on whether to move forward with the project, and several towns ultimately voted against the project (El Comercio 2007b). Observers noted that Zijin inherited the public relations nightmare surrounding Río Blanco (Vivas 2007). While local communities are often concerned about the environmental impact of mining, the mountainous region near the mine is remote and used by the drug trade to cultivate opium poppies for heroin. Thus, other observers, such as the Peruvian business federation, speculated that drug cartels were behind attacks on the Zijin offices in an effort to undermine the project (Business Daily Update 2009).

A particularly worrisome part of the story includes a group of Peruvian protesters who were allegedly tortured by Monterrico for their opposition. The group of 33 Peruvians was allegedly tortured by Monterrico after protesting the plans for a copper mine in 2005, and they successfully settled a lawsuit with Zijin over the incident in 2011 ("Zijin unit settles case over Peru torture claims" 2011). After sustained conflicts over the mine, Zijin pulled out of this project (Yam 2015). It is worth noting that Río Blanco was Zijin's only mining project in the Americas at the time. Thus, it is possible that the firm's lack of experience with the region played a role in the project's failure — or in Zijin's selection of a project that was exceedingly difficult to move forward. Nonetheless, this case illustrates how some Chinese firms have failed to garner the support of the local community.

By contrast, the Aluminum Corporation of China (Chinalco) has been much more successful in its high-profile Toromocho project. Chinalco is the world's second largest producer of aluminum and is seeking to further develop its production of other metals (Minera Chinalco Perú 2015). Chinalco is a state-owned enterprise (SOE) and the largest nonferrous metal enterprise in China (Li 2013). The company acquired the Toromocho mine in Peru in 2008, which is expected to produce copper, silver, and molybdenum over the next 35 years. Chinalco purchased the land for the Toromocho project without much fanfare, by acquiring its previous owner Peru Copper, a Canadian company. At the time of Chinalco's acquisition, the Toromocho project was estimated to yield US\$ 7.6 billion in tax revenue for the Peruvian state over 36 years and create 5,000 jobs (El Comercio 2008a). To finance the purchase, Chinalco obtained a loan from the state-owned Export-Import Bank of China, which is under the direct control of China's State Council (El Comercio 2008b).

\footnotetext{
${ }^{6}$ The former president of the Chamber of Commerce of Jaen was a vocal critic of a leader of the anti-Río Blanco protests, Gregorio Santos Guerrero. There has been some controversy over Santos, his intentions, and his financing (El Comercio 2012b).
} 
There was, however, one obstacle to developing Toromocho: the town of Morococha. Before developing Toromocho, Chinalco needed to relocate a town of 5,000 residents living on the mountain. To address this issue, Chinalco designed and built a planned community about a 15-minute drive away from the site and offered new homes to the relocated locals. The new town includes new roads, modest new houses with plumbing and electricity, new schools, a health clinic, and churches (Stauffer 2012). The new town was attractive to many residents as the old town lacked functional infrastructure and most homes did not have electricity or potable water. Prior to the move, a referendum was held, and a majority of local residents voted in favor of the move (Simpson 2008).

In this context, it was difficult for the opposition to the development of Toromocho to gain any momentum. They had little legal basis to prevent the acquisition of the mountain by Chinalco, since it was already a foreign concession. Despite the highprofile opposition of the president's brother to the project, there were no large civil society organizations, such as unions, willing to ally with the local opponents of the project. Although local and international NGOs have publicized negative portrayals of the operation, often in online blogs, these groups seem to represent a minority of residents and have little significant backing. Furthermore, a majority of the town of Morococha was in favor of the move, as Chinalco's new town represented a significant improvement in living conditions - despite concerns about the vulnerability of the new location to natural disasters. A vocal minority opposed the move on the grounds that compensation for residents' housing was too low and the site for the new town is susceptible to flooding. Despite protests led by the mayor of Morococha, the town had no legal recourse as it was located within the mining concession previously granted by the Peruvian government, and the relocation went forward in 2012 (Stauffer 2012).

There are a few lessons from the Toromocho project and Chinalco's relatively successful relocation of the town of Morococha. First, Chinalco acquired the mine from another foreign company that already owned the concession but was not developing it. Second, the scale of the project was huge, with the potential for significant tax revenue for the Peruvian state. Third, development of Toromocho was not for the fainthearted; to be successful, a mining enterprise needed to invest large sums in infrastructure development (for transport, energy, power plant, etc.) as well as to relocate the town of Morococha. This financing was possible for Chinalco as it had access to loans from a Chinese state-owned bank. Fourth, Chinalco utilized myriad tactics in negotiating with the local community: employed locals in the Peruvian division, built a wellappointed town with improved infrastructure, and even contracted a consultancy for advice on public relations from a social responsibility perspective (Collyns 2012). Although not all residents were satisfied with the outcome and additional concerns arose after the relocation, in the case of the Toromocho project, Chinalco seems to have exceeded international standards in its approach to this problem (Ray et al. 2015; Sanborn and Ching 2017).

Some of the mixed results of the statistical analysis could be attributed to the differential impacts of China in Peru, as illustrated by the Río Blanco and Toromocho cases. While some Peruvians may perceive Chinese investment as a boon for the economy and may benefit from new job opportunities, others may be concerned about environmental impacts or relocations. For example, in Junín, where the Toromocho project is located, we might expect more favorable impressions of China as compared to Piura where Río Blanco is 
located. Indeed, in 2012, when the town of Morococha was relocated, 72 percent of LAPOP respondents in Junín expressed trust in China, whereas that figure was only 56 and 55 percent in Piura and nationwide, respectively. However, this finding may be spurious as LAPOP's 2012 survey sampled relatively few respondents in Junín and Piura (see Table 3). In subsequent waves of LAPOP, trust in China was similar across respondents in Junín, Piura, and nationally. If the high trust in Junín in 2012 is not spurious, this finding might suggest that some Junín residents were initially persuaded by Chinalco's promise of Nueva Morococha. After the town's relocation, many residents have complained of a range of difficulties. In the 2014 LAPOP survey, respondents in Junín expressed lower trust than Piura and the national average (see Table 3). Nonetheless, in the 2017 and 2019 waves of LAPOP, respondents in Junín expressed similarly high levels of trust as those elsewhere in Peru, including Piura.

\section{Caveats}

These data are limited in several ways. The questions on trust in government suffer from severe nonresponse. Table 4 reports the percentage of nonsubstantial response (don't know, refuse to answer) for the trust and model country questions for each year. Nonresponse is particularly worrisome in 2012 and 2019, with over half of respondents choosing not to answer. Nonresponse is also somewhat higher in the China trust question as compared to the US trust question. Due to nonresponse, the sample size for the 2019 trust model is very low ( $n=265)$, which may compromise the results (see Table 4).

There are two possible explanations for high nonresponse in the China trust question. First, many Peruvians may not have an opinion regarding the trustworthiness of the Chinese government, despite China's active investments in Peru and frequent media coverage. In this case, as Chinese firms improve their approaches to corporate social responsibility and as China assists developing countries with the challenges of the COVID-19 pandemic, China has an opportunity to shape public opinion in its favor. It is reasonable to expect that Latin American public opinion toward China is more malleable than opinions of the United States, as the United States has a long and complex history in the region. Second, some Peruvians may hesitate to answer a question regarding trust in the Chinese government if they are employed by a Chinese firm. I expect that this situation would represent a small, hopefully negligible, proportion of respondents. Future research, particularly fieldwork, will be necessary to examine the possibility of self-censorship when Peruvians depend on Chinese firms for their livelihood.

Table 3 Percent Expressing Trust in China: Junín, Piura, and Nationally

\begin{tabular}{ccccccc}
\hline Year & Junín & Observations in Junín & Piura & Observations in Piura & National average & Total observations \\
\hline 2012 & $72 \%$ & 29 & $56 \%$ & 32 & $55 \%$ & 566 \\
2014 & $30 \%$ & 53 & $37 \%$ & 67 & $42 \%$ & 1178 \\
2017 & $58 \%$ & 106 & $56 \%$ & 61 & $61 \%$ & 1505 \\
2019 & $67 \%$ & 18 & $67 \%$ & 18 & $54 \%$ & 360 \\
\hline
\end{tabular}

Source: The AmericasBarometer by the Latin American Public Opinion Project (LAPOP), www. LapopSurveys.org 
Table 4 Nonsubstantial Response in Trust and Model Country Questions

\begin{tabular}{lccc}
\hline Year & Trust Chinese Government & Trust US Government & Model Country \\
\hline 2012 & $62 \%$ & $59 \%$ & $58 \%$ \\
2014 & $21 \%$ & $15 \%$ & $14 \%$ \\
2017 & $43 \%$ & $29 \%$ & $9 \%$ \\
2019 & $76 \%$ & $68 \%$ & N/A \\
\hline
\end{tabular}

Source: The AmericasBarometer by the Latin American Public Opinion Project (LAPOP), www. LapopSurveys.org

Some multicollinearity among the independent variables in the models is present, but not to a great extent. Trust in the Chinese and US governments is correlated, but not to a worrisome degree. ${ }^{7}$ Education is also correlated with trust at a similar level as the two trust variables.

Coding Chinese investment by departamento lacks some granularity. However, this is the smallest unit possible given the available information of Chinese investment and the units in the LAPOP data.

The question regarding trust in the Chinese government may not be the most appropriate question to elucidate Peruvians' opinions of Chinese actors. In this analysis, I assume that, due to likely collaboration between Chinese firms and the Chinese government, the actions of Chinese firms will reflect on the Chinese government, either well or poorly. However, some Peruvians may disaggregate between the Chinese government and other Chinese actors, such as firms or Chinese nationals. As evident from studies of global public opinion of the United States, many people are quite capable of distinguishing US policy from US leadership. ${ }^{8}$ The same may be true of global perceptions of China. Future studies should consider examining more nuanced data to parse the effects of China's global impact on public opinion.

\section{Conclusion}

China continues to have a positive impression overall in Peru, especially when compared with the United States, but the data do not suggest that most Peruvians would support adopting China's political or economic system as a model for their own country. Peruvians appear divided between China, Japan, and the United States regarding a country to emulate. Moreover, Peruvians who strongly value democracy are less likely to choose China as a model, and high proportions of Peruvians prefer democracy. Thus, I do not find evidence of authoritarian diffusion. Rather, it seems that democratic values may be associated with resistance to a China model. These findings suggest that scholars of authoritarian diffusion should also consider whether a country is receptive to emulating an authoritarian model. Local conditions, such as widespread democratic values, may impact the likelihood of authoritarian diffusion.

\footnotetext{
${ }^{7}$ Correlation coefficient of 0.26 in the 2017 wave, for example.

${ }^{8}$ See footnote 3 for a discussion of this issue.
} 
The inconclusive results of some variables and the high rates of nonresponse suggest that Chinese actors have the potential to shape public opinion, particularly in Latin America, where intense exchange is relatively recent. Experience with Chinese extractive projects may dampen trust in China in some instances but may also provide an example of China as an effective engine of economic growth. Rural residents who live in a region with Chinese investment may be particularly persuaded by the potential of a "China model" to improve their economic conditions.

Chinese actors, both firms and the party-state, are learning how to improve relations with Latin Americans. Chinese firms seem to be improving their ability to assuage the concerns of host communities. Moreover, the Chinese government uses aid strategically. Through these efforts, China may be able to increase general sympathy and goodwill in Peru. A plausible extrapolation of my findings could be that Peruvians might be more sympathetic to China than the United States in an international dispute, but many more attitudes would need to shift before Peruvians would wholeheartedly support emulating the Chinese political system.

China has not supplanted the United States in Latin America yet. China's efforts at cultivating soft power through improved public relations may have offset some of the negative publicity from contentious mining projects, resulting in improved perceptions over time. China has the potential to cultivate stronger alliances in Latin America, especially where economic complementarities exist, but the party-state's political appeal may be limited in stable democracies. Meanwhile, as the United States works to regain its international credibility, China has an opportunity to deepen its relationship with countries like Peru.

\section{Appendix}

Table 52019 summary statistics

\begin{tabular}{lccccc}
\hline Variable & Obs & Mean & Std. Dev. & Min & Max \\
\hline Chinese investment & 1521 & 0.66 & 0.48 & 0 & 1 \\
Follows the news & 1516 & 0.91 & 0.29 & 0 & 1 \\
Ideology (rightist) & 1444 & 5.43 & 2.51 & 1 & 10 \\
Democracy is best form of gov't & 1496 & 4.44 & 1.49 & 1 & 7 \\
Proud of Peruvian political system & 1505 & 3.46 & 1.74 & 1 & 7 \\
Trust Chinese gov't & 360 & 0.54 & 0.50 & 0 & 1 \\
Trust US gov't & 481 & 2.24 & 0.92 & 1 & 4 \\
Sex & 1520 & 1.50 & 0.50 & 1 & 2 \\
Age & 1520 & 38.85 & 15.54 & 18 & 91 \\
Education & 1487 & 11.68 & 3.74 & 0 & 18 \\
Income & 1392 & 7.43 & 4.75 & 0 & 16 \\
\hline
\end{tabular}


Table 62017 summary statistics

\begin{tabular}{|c|c|c|c|c|c|}
\hline Variable & Obs & Mean & Std. Dev. & Min & Max \\
\hline China as a model for Peru & 2422 & 0.25 & 0.43 & 0 & 1 \\
\hline Chinese investment & 2647 & 0.50 & 0.50 & 0 & 1 \\
\hline Follows the news & 2635 & 0.89 & 0.31 & 0 & 1 \\
\hline Ideology (rightist) & 2470 & 5.41 & 2.61 & 1 & 10 \\
\hline Democracy is best form of gov't & 2596 & 4.50 & 1.58 & 1 & 7 \\
\hline Proud of Peruvian political system & 2611 & 3.74 & 1.75 & 1 & 7 \\
\hline Trust Chinese gov’t & 1505 & 2.66 & 0.90 & 1 & 4 \\
\hline Trust US gov’t & 1881 & 2.24 & 0.90 & 1 & 4 \\
\hline Sex & 2647 & 1.50 & 0.50 & 1 & 2 \\
\hline Age & 2647 & 38.75 & 14.77 & 18 & 86 \\
\hline Education & 2597 & 11.18 & 3.97 & 0 & 18 \\
\hline Income & 2434 & 7.73 & 5.13 & 0 & 16 \\
\hline
\end{tabular}

Table 72014 summary statistics

\begin{tabular}{lccccc}
\hline Variable & Obs & Mean & Std. Dev. & Min & Max \\
\hline China as a model for Peru & 1291 & 0.19 & 0.39 & 0 & 1 \\
Chinese investment & 1500 & 0.56 & 0.50 & 0 & 1 \\
Follows the news & 1453 & 0.93 & 0.26 & 0 & 1 \\
Ideology (rightist) & 1250 & 5.52 & 2.03 & 1 & 10 \\
Democracy is best form of gov't & 1434 & 4.75 & 1.62 & 1 & 7 \\
Proud of Peruvian political system & 1462 & 3.69 & 1.60 & 1 & 7 \\
Trust Chinese gov't & 1178 & 2.27 & 0.82 & 1 & 4 \\
Trust US gov't & 1277 & 2.55 & 0.84 & 1 & 4 \\
Sex & 1500 & 1.50 & 0.50 & 1 & 2 \\
Age & 1500 & 39.94 & 15.53 & 18 & 87 \\
Education & 1497 & 10.96 & 3.95 & 0 & 18 \\
Income & 1172 & 8.92 & 4.75 & 0 & 16 \\
\hline
\end{tabular}


Table 82012 summary statistics

\begin{tabular}{lccccc}
\hline Variable & Obs & Mean & Std. Dev. & Min & Max \\
\hline China as a model for Peru & 627 & 0.20 & 0.40 & 0 & 1 \\
Chinese investment & 1500 & 0.55 & 0.50 & 0 & 1 \\
Follows the news & 1485 & 0.91 & 0.29 & 0 & 1 \\
Ideology (rightist) & 1285 & 5.60 & 2.00 & 1 & 10 \\
Democracy is best form of gov't & 1461 & 4.81 & 1.50 & 1 & 7 \\
Proud of Peruvian political system & 1473 & 4.01 & 1.48 & 1 & 7 \\
Trust Chinese gov't & 566 & 2.54 & 0.82 & 1 & 4 \\
Trust US gov't & 622 & 2.62 & 0.87 & 1 & 4 \\
Sex & 1500 & 1.50 & 0.50 & 1 & 2 \\
Age & 1500 & 39.38 & 15.69 & 18 & 89 \\
Education & 1499 & 11.01 & 3.96 & 0 & 18 \\
Income & 1312 & 7.84 & 3.56 & 1 & 16 \\
\hline
\end{tabular}

Acknowledgements I am grateful to the Foreign Policy Institute at the Johns Hopkins University School of Advanced International Studies (SAIS) and Amherst College for supporting this project. I am deeply indebted to Siyi Li, Arin Lizarraga, and Robert Parker for insights that shaped this research in its early stages and especially to Bonnie Lin for her ideas and data collection. I thank the Latin American Public Opinion Project (LAPOP) and its major supporters (the United States Agency for International Development, the Inter-American Development Bank, and Vanderbilt University) for making the data available. Earlier versions of this research were presented at the American Political Science Association 2019 Annual Meeting, the "Getting China Right" conference at Duke University in 2019, and the Association of Chinese Political Studies 2020 Annual Meeting at Middlebury College. Many thanks to the attendees of these meetings for their thoughtful comments and questions. I am especially grateful to Xiaoyu Pu and the anonymous reviewers for their incisive comments. Many thanks to Melanie Manion and Yuhua Wang for organizing the special issue. All errors are my own.

\section{References}

Agadjanian A, Horiuchi Y. Has Trump damaged the U.S. image abroad? Decomposing the effects of policy messages on foreign public opinion. Polit Behav. 2020;42(2):581-602.

Aldrich JH, Lu J. How the public in the US, Latin America, and East Asia sees an emerging China. Eur Rev. 2015;23(2):227-41.

Ambrosio T. Constructing a framework of authoritarian diffusion: Concepts, dynamics, and future research. Int Stud Perspect. 2010;11(4):375-92.

Ambrosio T. The rise of the 'China Model' and 'Beijing Consensus': Evidence of authoritarian diffusion? Contemp Polit. 2012;18(4):381-99.

Armony AC, Velásquez NG. Anti-Chinese sentiment in Latin America: an analysis of online discourse. J Chin Polit Sci. 2015;20(3):319-46.

Armony AC, Velásquez NG. (2016) A honeymoon with China?: Public perceptions in Latin America and Brazil. Uma lua de mel com a China? : Percepções públicas na América Latina e no Brasil [Internet]. 2016 Jul [cited 2019 Aug 25]; Available from: http://repositorio.ipea.gov.br/handle/11058/6539. Accessed 4 March 2021

Bialik K. How the world views the U.S. and its president in 2018 in 9 charts [Internet]. Pew Research Center. [cited 2020 Nov 25]. Available from: https://www.pewresearch.org/fact-tank/2018/10/09/how-the-worldviews-the-u-s-and-its-president-in-9-charts/2018/10/09/how-the-world-views-the-u-s-and-its-president-in9-charts/. Accessed 25 Nov 2020

Brownlee J. The limited reach of authoritarian powers. Democratization. 2017;24(7):1326-44. 
Business Daily Update. Drug cartel behind Zijin Peru copper project attack. Industry Updates (China) [Internet]. 20095 [cited 2015 May 24]; Available from: http://infoweb.newsbank.com/resources/doc/ nb/news/12BCEF5F27651928?p=AWNB. Accessed 24 May 2015

Castañeda N. New dependency?: Economic links between China and Latin America. Issues Stud. 2017;53(1):1-33.

Collyns D. Chinese mining firm to raze Peruvian peak for 35 years of mineral wealth. The Guardian [Internet]. 201220 [cited 2019 Aug 26]; Available from: https:/www.theguardian.com/world/2012/dec/20/chinesemining-peru-corporate-responsibility2012/dec/20/chinese-mining-peru-corporate-responsibility. Accessed 20 April 2015

El Comercio. Lanzan oferta por la minera Monterrico. El Comercio (Lima, Peru) [Internet]. 2007a 6 [cited 2015 May 23]; Available from: http://infoweb.newsbank.com/resources/doc/nb/news/ 1301A130B63D3548?p=AWNB

El Comercio. Zijin lista para entrar en proyecto Río Blanco. El Comercio (Lima, Peru) [Internet]. $2007 \mathrm{~b} 14$ [cited 2015 May 23]; Available from: http://infoweb.newsbank.com/resources/doc/nb/news/ 1301A13E555A3790?p=AWNB

El Comercio. Firma china adquiere 38\% de Monterrico. El Comercio (Lima, Peru) [Internet]. 2007 c 28 [cited 2015 May 23]; Available from: http://infoweb.newsbank.com/resources/doc/nb/news/ 1301A143D19A0AE0?p=AWNB

El Comercio. Toromocho dará 5.000 puestos de trabajo. El Comercio (Lima, Peru) [Internet]. 2008 a 6 [cited 2015 May 22]; Available from: http://infoweb.newsbank.com/resources/doc/nb/news/ 135C3E2A9DFFB7D0?p=AWNB

El Comercio. El acuerdo entre Chinalco y Eximbank of China es por US\$2.000 millones. El Comercio (Lima, Peru) [Internet]. 2008b [cited 2015 May 22]; Available from: http://infoweb.newsbank.com/resources/ doc/nb/news/135C3E5F63F2D9B0?p=AWNB

El Comercio. Gregorio Santos y los lobbies mineros. El Comercio (Lima, Peru) [Internet]. 2012a [cited 2015 May 23]; Available from: http://infoweb.newsbank.com/resources/doc/nb/news/13DD13525A99FB78?p=AWNB

El Comercio. Santos nos debe explicar. El Comercio (Lima, Peru) [Internet]. 2012b 30 [cited 2015 May 24]; Available from: http://infoweb.newsbank.com/resources/doc/nb/news/13DD686D5E527B50?p=AWNB

EFE. Peru, China strengthen trade relations. BBC Selected Newspaper Articles: Peru [Internet]. 2009 [cited 2015 May 23]; Available from: http://infoweb.newsbank.com/resources/doc/nb/news/ 12BF58C0DE508F20?p=AWNB

Fravel MT, Manion M, and Wang Y. A "China in the World" Paradigm for Scholarship. Studies in Comparative International Development. 2021.

Gallagher KP, Irwin A. China's economic statecraft in Latin America: evidence from China's policy banks. In: Myers M, Wise C, editors. The Political Economy of China-Latin America Relations in the New Millennium: Brave New World. New York: Routledge; 2017. p. 50-68.

Gonzalez-Vicente R. The internationalization of the Chinese state. Polit Geogr. 2011 Sep;30(7):402-11.

Guo J, Myers M. Chinese agricultural investment in Latin America: Less there than meets the eye? In: Myers M, Wise C, editors. The Political Economy of China-Latin America Relations in the New Millennium: Brave New World. New York: Routledge; 2017. p. 92-114.

Irwin A, Gallagher KP. Chinese mining in Latin America: A comparative perspective. J Environ Dev. 2013;22(2):207-34.

Kastner S, Pearson M. Exploring the Parameters of China's Economic Influence. Studies in Comparative International Development. 2021.

Kennedy S. The myth of the Beijing Consensus. J Contemp China. 2010 Jun;19(65):461-77.

LAPOP. The AmericasBarometer by the Latin American Public Opinion Project (LAPOP). 2012. www. LapopSurveys.org. Accessed 11 Mar 2021.

LAPOP. The AmericasBarometer by the Latin American Public Opinion Project (LAPOP). 2014. www. LapopSurveys.org. Accessed 11 Mar 2021.

LAPOP. The AmericasBarometer by the Latin American Public Opinion Project (LAPOP). 2017. www. LapopSurveys.org. Accessed 11 March 2021.

LAPOP. The AmericasBarometer by the Latin American Public Opinion Project (LAPOP). 2019. www. LapopSurveys.org. Accessed 11 Mar 2021.

Li, X. More than Meets the Eye: Understanding Perceptions of China beyond the Favorable-Unfavorable Dichotomy. Studies in Comparative International Development. 2021.

Li S. China's copper mine starts production in Peru [Internet]. China.org.cn. 2013 [cited 2015 May 22]. Available from: http://www.china.org.cn/business/2013-12/13/content_30888050.htm

Minera Chinalco Perú. Proyecto Toromocho [Internet]. Minera Chinalco Perú. 2015 [cited 2015 May 21]. Available from: http:/www.chinalco.com.pe/en/chinalco. Accessed 21 May 2015 
Ray R, Gallagher KP, Lopez A, Sanborn C. China in Latin America: Lessons for south-south cooperation and sustainable development [Internet]. Boston University Global Economic Governance Initiative; 2015 Apr p. 1-25. Available from: http://www.bu.edu/pardeeschool/files/2015/04/Working-Group-Final-ReportPages1.pdf2015/04/Working-Group-Final-Report-Pages1.pdf. Accessed 4 March 2021

Sanborn C, Ching VC. Chinese-Peruvian relations in the mining sector: Learning step by step. In: Myers M, Wise C, editors. The Political Economy of China-Latin America Relations in the New Millennium: Brave New World. New York: Routledge; 2017. p. 115-40.

Simpson J. Peru's "copper mountain" in Chinese hands. BBC [Internet]. 2008 [cited 2015 May 22]; Available from: http://news.bbc.co.uk/2/hi/americas/7460364.stm. Accessed 22 May 2015

Stallings B. Chinese foreign aid to Latin America: Trying to win friends and influence people. In: Myers M, Wise C, editors. The Political Economy of China-Latin America Relations in the New Millennium: Brave New World. New York: Routledge; 2017. p. 69-91.

Stauffer C. Chinese miner builds high-altitude experiment in Peru [Internet]. Reuters India. 2012 [cited 2015 May 22]. Available from: http://in.reuters.com/article/2012/07/01/peru-mining-chinalco-idINL1E8HJLRE20120701

Strauss JC. Framing and claiming: Contemporary globalization and going out in China's rhetoric towards Latin America. China Q. 2012;209:134-56.

Su Y-P, Vargas Delgado O-R. Is China becoming a hegemonic challenge in Latin America and the Caribbean? A political economy analysis of the Nicaragua interoceanic canal project. Issues Stud. 2017;53(1):1.

Vivas F. Majaz impedirás. El Comercio (Lima, Peru) [Internet]. 200713 [cited 2015 May 23]; Available from: http:// infoweb.newsbank.com/resources/doc/nb/news/1301A1758E8748B8?p=AWNB. Accessed 23 May 2015

Weyland K. Autocratic diffusion and cooperation: The impact of interests vs. ideology. Democratization. 2017;24(7):1235-52.

Wike R, Stokes B, Poushter J, Silver L, Fetterolf J, Devlin K. Trump approval worldwide remains low especially among key allies [Internet]. Pew Research Center's Global Attitudes Project. 2018 [cited 2020 Nov 25]. Available from: https://www.pewresearch.org/global/2018/10/01/trumps-international-ratingsremain-low-especially-among-key-allies/2018/10/01/trumps-international-ratings-remain-low-especiallyamong-key-allies/. Accessed 25 Nov 2020

Wike R, Poushter J, Fetterolf J, Schumacher S. Trump ratings remain low around the world, while views of U.S. stay mostly favorable [Internet]. Pew Research Center's Global Attitudes Project. 2020 [cited 2020 Nov 25]. Available from: 2020 https://www.pewresearch.org/global/2020/01/08/trump-ratings-remainlow-around-globe-while-views-of-u-s-stay-mostly-favorable/2020/01/08/trump-ratings-remain-lowaround-globe-while-views-of-u-s-stay-mostly-favorable/. Accessed 25 Nov 2020

Wolf J. U.S. lawmakers seek to block China Huawei, ZTE U.S. inroads. Reuters [Internet]. 2012 [cited 2015 May 21]; Available from: http://www.reuters.com/article/2012/10/08/us-usa-china-huawei-zteidUSBRE8960NH201210082012/10/08/us-usa-china-huawei-zte-idUSBRE8960NH20121008. Accessed 21 May 2015

Xi, Jinping. Full text of Xi Jinping's report at 19th CPC National Congress [Internet]. Xinhua. 2017 [cited 2019 Nov 4]. Available from: http:/www.xinhuanet.com/english/special/2017-11/03/c_136725942. htm2017-11/03/c_136725942.htm. Accessed 4 March 2021

Yam P. China's Zijin in talks to buy gold, copper mines abroad. Reuters [Internet]. 2015 [cited 2015 May 24]; Available from: http://www.reuters.com/article/2015/03/23/zijinmining-results-maidUSL3N0WP3IQ201503232015/03/23/zijinmining-results-ma-idUSL3N0WP3IQ20150323. Accessed 24 May 2015

Zijin unit settles case over Peru torture claims. Reuters [Internet]. 2011 [cited 2015 May 24]; Available from: http://www.reuters.com/article/2011/07/20/zijin-peru-idAFN1E76J01F201107202011/07/20/zijin-peruidAFN1E76J01F20110720. Accessed 24 May 2015

Publisher's Note Springer Nature remains neutral with regard to jurisdictional claims in published maps and institutional affiliations.

Kerry Ratigan is an Assistant Professor of Political Science at Amherst College. From 2018 to 2020, she was also the Pre-tenure Fellow for China-Latin America-US Affairs at the Foreign Policy Institute at the Johns Hopkins School of Advanced International Studies (SAIS). Her research focuses on Chinese politics, social policy, decentralization, and state-society relations, including extensive work on health policy adoption and implementation in rural China. Her forthcoming book, Let Some Get Healthy First, examines how local politics shape social policy provision in China. She received her Ph.D. in Political Science from the University of Wisconsin-Madison. 